University of Rhode Island

DigitalCommons@URI

Open Access Master's Theses

2005

\title{
An Examination of the Relationship Between Student Satisfaction and Instructional Mode
}

Danielle Alfano

University of Rhode Island

Follow this and additional works at: https://digitalcommons.uri.edu/theses

\section{Recommended Citation}

Alfano, Danielle, "An Examination of the Relationship Between Student Satisfaction and Instructional Mode" (2005). Open Access Master's Theses. Paper 985.

https://digitalcommons.uri.edu/theses/985

This Thesis is brought to you for free and open access by DigitalCommons@URI. It has been accepted for inclusion in Open Access Master's Theses by an authorized administrator of DigitalCommons@URI. For more information, please contact digitalcommons-group@uri.edu. 
AN EXAMINATION OF THE RELATIONSHIP BETWEEN STUDENT SATISFACTION AND INSTRUCTIONAL MODE BY

DANIELLE ALFANO

A THESIS SUBMITTED IN PARTIAL FULFILLMENT OF THE REQUIREMENTS FOR THE DEGREE OF MASTER OF ARTS

IN

COMMUNICATION STUDIES

UNIVERSITY OF RHODE ISLAND

2005 


\section{MASTER OF ARTS THESIS}

\section{OF}

DANIELLE ALFANO

APPROVED:

Thesis Committee:

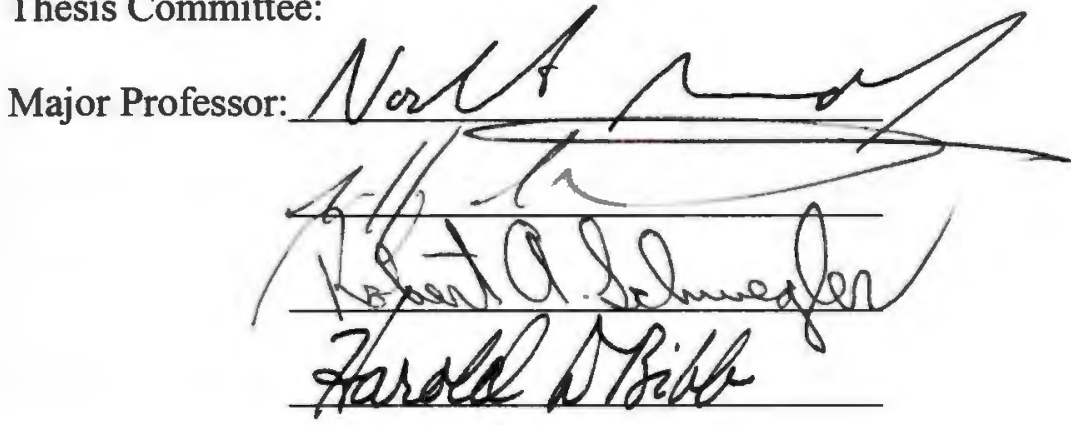

DEAN OF THE GRADUATE SCHOOL

UNIVERSITY OF RHODE ISLAND 


\begin{abstract}
Increased technology in the university setting, mainly with course instruction has aroused considerable attention on student satisfaction and quality of work. However, few studies have investigated these two concepts together. The present study aims to provide some incite in this line of research with an examination between student satisfaction and the quality of work based on the mode of instruction. Ninety students at the University of Rhode Island in the upper level Communication 381 Research Methods course participated in this study. The results indicate that significantly positive relationships exist among the dimensions of the two concepts. Limitations and directions for future research are discussed as well.
\end{abstract}




\section{Acknowledgements}

The writing of thesis can be a long and tedious experience, yet mine is a happy and valuable journey with support from many people.

I am indebted to my esteemed advisor, Dr. Norbert Mundorf. He is always there supporting me and answering all my questions throughout every step of the way with his wide knowledge and welcoming personality. It was a great pleasure to conduct this thesis under his supervision. This thesis would not have been possible without his expert guidance, stimulating suggestions and encouragement.

Sincere thanks go to Dr. Geoff Leatham for his constructive suggestions and to Dr. Robert Schwegler for his valuable opinions. Both of them provided me tremendous assistance throughout this work.

I would like to express my deep gratitude to Dr. Sylvia C. Spears, chair of my thesis defense. Without her support and service, the defense would not have been as smooth a process.

Many on the faculty and staff of the Department of Communication Studies assisted and encouraged me in numerous ways during my ongoing studies at the University of Rhode Island. I am especially grateful to Dr. Lynne Derbyshire and Dr. Julia Johnson for providing me a chance as an instructor of communication. In this position, I found my teaching style and continued my learning as well.

I am grateful to all of my colleagues at the Department of Communication Studies for their tremendous support in both teaching and writing this thesis. 


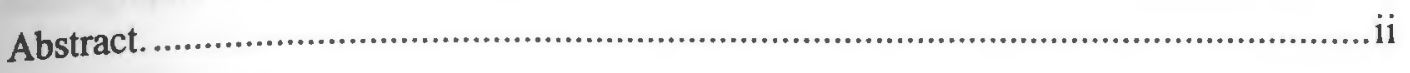

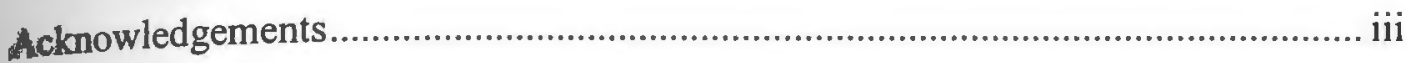

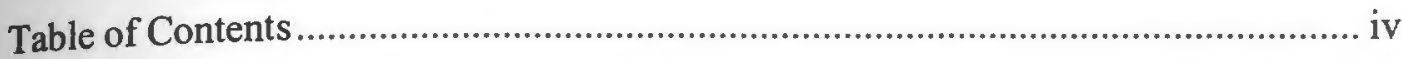

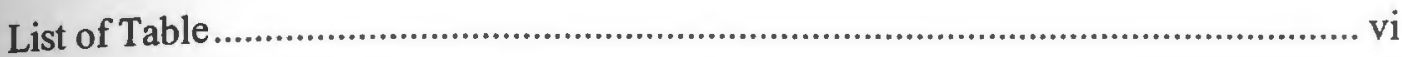

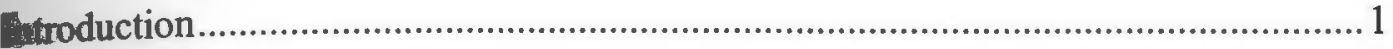

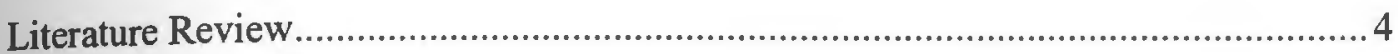

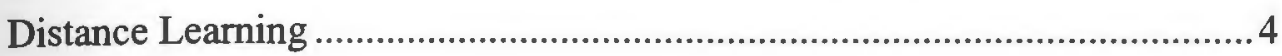

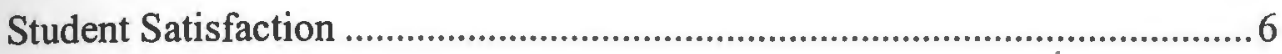

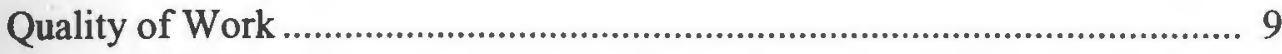

Expected Relationships between Student Satisfaction, Mode of

Instruction, and Quality of Work ................................................................... 11

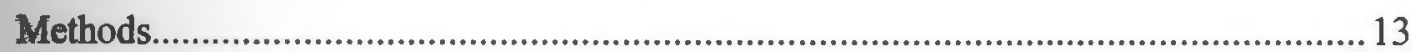

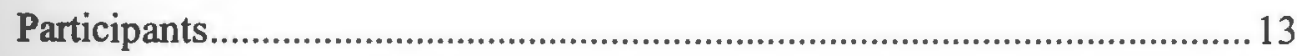

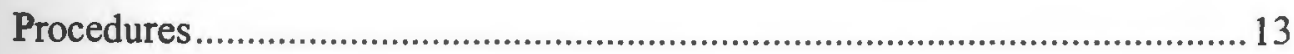

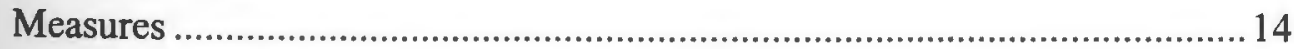

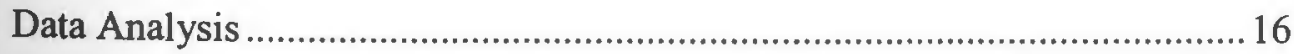

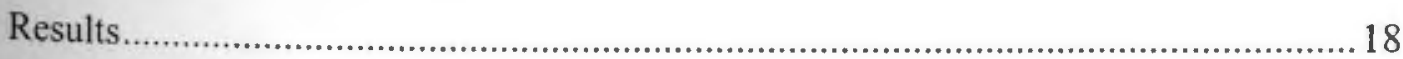

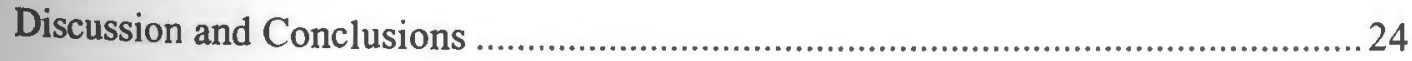

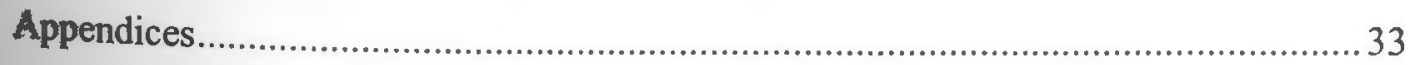

Appendix A. Consent Form for Participants................................................... 33

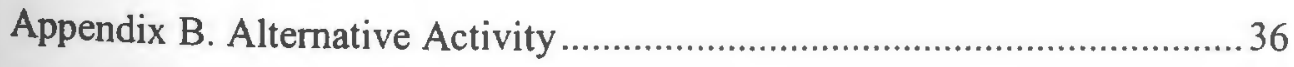

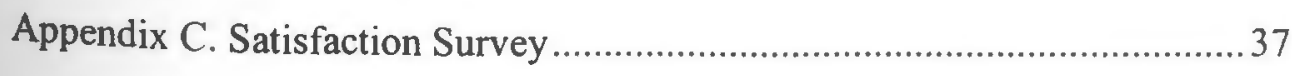




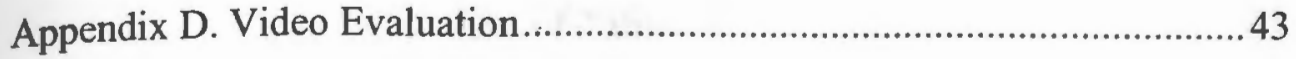

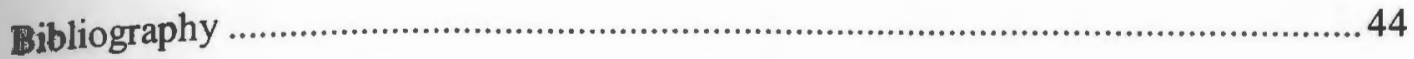


List of Table

Table

Page

1. Means of Satisfaction Scale Based on Gender ............................................20 


\section{Introduction}

With the rapid development of technology and the increasing number of schools offering courses online, student satisfaction needs to be considered when determining the manner in which a course is offered (Pelz, 2004; Roach, 2004). The wide-ranged expansion of online courses on the one hand calls for faculty and institutions interest in student satisfaction; on the other hand, the work that is produced in the courses still needs to be held to the same quality level as the traditional face-to-face courses. Student satisfaction and productivity have thus received considerable attention in previous decades (e.g. Clark, 2002; Dick \& Hanna, 2002; Egan, Sebastian \& Welch, 1991; Kassop, 2003; Martin \& Rainey, 1993; Sehoole \& Moja, 2003; Souder, 1993).

With the demographic changes in the student body, the increase in non-traditional students, and the emergence of online education systems, there is an increasing interest in online education (e.g., Annison, 2002; Biner, Bink, Huffman \& Dean, 1995; Kuiik \& Kulik, 1991). Most US colleges and universities now offer at least some courses via the Internet (Clarke, R. D., 1999). Web based learning is often called online learning or elearning because it includes online course content. Discussion forums via email, chat boards, live lectures, and videoconferencing are all possible through the web. Web based courses may also provide static pages such as printed course materials.

Few studies have tested the true value of distance education (online learning). There are common misconceptions regarding distance learning or e-learning courses. Donald Clark (2002) identifies nine of these myths. To state "e-learning is just another method of delivery" may be one of the most popular and inaccurate myths (Clark, 2002, p.598). A combination of psychological concepts needs to be considered. 
The second major misconception is that "e-learning is less effective than traditional methods of learning" (Clark, 2002, p. 599). With more and more options to take courses in the nontraditional manner of distance learning, some critics have questioned whether the learning is accurate. To address this issue, the researcher must take into consideration that students learn by utilizing a wide range of tools. Some students understand information if it is presented into a pictorial image, while other thrive on facts being presented to them. The assumption that e-learning is less effective generalizes too broadly (Clark, 2002; Dick \& Hanna, 2002; Egan, Sebastian \& Welch, 1991; Kassop, 2003; Martin \& Rainey, 1993; Souder, 1993).

It is understood that the ability to ask questions and interact with fellow classmates and the instructor is a key element for a successful experience in a course. Kubala (2000) states the "one problem commonly associated with traditional distance education is the lack of opportunity for collaborative work, debate, dialogue, and conversational learning" (p. 333). The statement supports the notion that having absolutely no face-to-face interaction might hinder the learning process. To be successful in a course, no matter the mode of instruction, a student needs to be an active learner, which includes engaging with classmates and the professor (Kassop, 2003; Kubala, 2000). On-line courses are mostly effective if the student is motivated, which is an issue needing to be addressed. The instructor needs to find ways for the student to attend weekly class meetings along with completing the on-line material. Clark (2002) considers this notion by clearly stating, "training is still synonymous with classrooms and teachers" (p. 600). The motivation has to come from the student along with the instructor. Charts, online discussions, and face-to-face interaction need to entice the 
student to keep him/her motivated. No matter how a course is taught, there are moments when the majority of students lack motivation due to personal issues or even the material itself. It needs to be clear that motivation is necessary for any type of course that is taught whether it be online or face-to-face. If the motivation is lacking, the success of the learning will be ultimately low (Clark, 2002, p. 600).

Witt (2003) describes the "ideal model" of how a course should be set up. $\mathrm{He}$ states, most instructors "consider the websites to be essential to successful course designs" (Witt, 2003, p. 435). The majority of those instructors agreed that using a webcomponent is helpful and can only further the students' educational ability. The paper concludes with a discussion of what this study has in store for the present and the future. The most important concern is that traditional courses should implement some form of a web-component in order to reach students with another style of learning. Some question whether the students taking courses in this manner are truly learning and retaining the information as much as those who take a traditional course. The purpose of this study is to re-envision the facilitation of student learning by investigating/analyzing the relationship between pedagogical style and student satisfaction. 


\section{Literature Review}

\section{Distance Learning}

The increasing use of technology in today's society has a major impact on the design of higher education. Since the introduction of distance learning more than 100 years ago utilizing correspondence courses in paper form, to what distance learning has evolved to in the year 2005, distance education is continually changing to meet the needs of students (eLRN Network, 2001; Saba, 2001). Before distance learning, students would all need to be in the same location for the same period of time each day the class would meet. Due to programs such as the University of Phoenix (an online for-profit university), this is no longer the case. Students can take classes in any location, at any time, and they never have to go to a "classroom" (Dick \& Hanna, 2002).

With more and more individuals seeking higher education, the question that arises most is "Is this a valid and effective method of instruction?" (Dick \& Hanna, 2002; Egan, Sebastian \& Welch, 1991; Kassop, 2003; Martin \& Rainey, 1993; Souder, 1993). Research indicates that the instructional format itself has little effect on student achievement (Martin \& Rainey, 1993; Souder, 1993).

Martin and Rainey (1993) found no significant difference in the positive attitudes of students toward courses whether the course was offered online or face-to-face. Their study investigated the effect of satellite-delivered instruction on student achievement and attitude in a high school anatomy and physiology course. The experimental group included students from seven high schools enrolled in the satellite-delivered course, while the control group consisted of students from seven high schools in which classroom teachers provided instruction. Two hypotheses were tested using the t-test for dependent 
samples. The findings showed that there was no significant difference between the experimental group and control group in attitude toward the classes. However, on the achievement test the mean score of the experimental group was significantly higher than that of the control group (Martin \& Rainey, 1993). This study supports the idea that the mode of instruction has no affect on student satisfaction.

Egan, Sebastian \& Welch (1991) and Whittington (1987) noted that the traditional face-to-face instruction is perceived by students to be more clearly presented and to maintain a better organizational element than distance education. Teachers must be properly trained both in the use of equipment and in those techniques proven effective in the distance learning environment. Learners get more out of the courses when the instructor seems comfortable with the technology, maintains good eye contact with the equipment, repeats questions and possesses a sense of humor (Egan, Sebastian \& Welch 1991; Martinson, 2000). This could be one explanation why students showed no significant difference in their attitudes toward the method the course was taught. One possible reason could be the instructors themselves. No matter what method the course was taught by, face-to-face or online, if the instructor was not comfortable then the students would not be as satisfied with the course (Egan, Sebastian \& Welch 1991; Kelly \& Schorger, 2002; Martinson, 2000; Pelz, 2004). As long as the form in which the course is delivered is equally available to all the participants, that would be an indication for further research in what makes an effective and well-presented distance education course, including how effective is the training the instructors are given (Martin \& Rainey, 1993; Souder, 1993). 
Student Satisfaction

In the society in which we live, one of the prevailing notions is to view people as consumers. Higher education is no exception to this trend. Dick \& Hanna (2002), Levin (2005), and Martinson (2000) suggest that higher education institutions should view students as consumers and not just as individuals seeking knowledge. Snare (1997) mentions that even though it seems appropriate, the student as consumer analogy is harmful. The analogy "lowers quality, refocuses valuable resources, encourages passive learning, and undermines social and civic values" (Snare, p. 122). The university considered as a business carries with it the idea of students as consumers in an educational marketplace. As the well known scholar David Reisman (1981) noted years ago, "this shift from academic merit to student consumerism is one of the two greatest reversals of direction in all the history of American higher education; the other being the replacement of the classical college by the modern university a century ago" (p. xi). From this model, it follows that students are consumers of instruction and therefore have a right to evaluate and influence instruction.

One of the major factors to be considered regarding student satisfaction is the mode of instruction. There are three main methods in which a course is taught: traditional face-to-face, hybrid or blended which is a combination of face-to-face and online, and completely online which is also known as distance learning (Kassop, 2003; Sener \& Humbert, 2002). In addition, within online Distance Learning a major distinction is found between synchronous (real-time, e.g. chat) and asynchronous (time delayed, e.g. bulletin board postings) instruction (Baer, 2000; Pelz, 2004). Some instructors combine both methods. 
Each of the three modes has its own positive and negative aspects (Barbian, 2002; Belcheir \& Cucek, 2001; Kassop, 2003; Sener \& Humbert, 2002). Some of the noted positive aspects for hybrid and distance learning courses are the flexibility of time, the tendency to be more student-centered learning and more comfortable in online class discussions (Allen \& Pilant, 2000; Barbian, 2002; Kassop, 2003; Sener \& Humbert, 2002; Stokes, 2003; Sullivan, 2001; Taplin \& Jegede, 2001). Some of the noted negative aspects for hybrid and distance learning courses are technology issues, less interaction with professor, and motivational concerns (Belcheir \& Cucek, 2001; Dick \& Hanna, 2002; Kelly \& Schorger, 2002; Shea, Fredericksen, Pickett, Pelz, \& Swan, 2001; Stokes, 2003). The traditional face-to-face method has the benefit of students being able to get hands on help and guidance from the professor along with reading nonverbal cues from the professor and classmates (Arbaugh, 2001; Kubala, 2000; Swan, 2002; Witt, 2003). On the other hand, Distance Learning courses encourage quality student writing, which is a major deficit in the current college population (Clark, 2002; Dick \& Hanna, 2002; Kassop, 2003).

Some studies have shown a preference by older students and women in taking online courses, while other studies show that there is no difference in preference to the mode of instruction. Sullivan (2001) states, "online courses benefit a wide variety of students, but perhaps none more dramatically than nontraditional female students" (p. 817). Nontraditional aged students refer to those students over the age of 25 (Sullivan, 2001, p. 806). The main reasons for this trend would be the flexibility to take the courses at the convenience of the individuals' schedule including children, community Commitment, family, work, and the course obligations (Allen \& Pilant, 2000; Belcheir \& 
Cucek, 2001; Stokes, 2003; Sullivan, 2001; Taplin \& Jegede, 2001). To further support the importance of scheduling issues, Clark (2002) notes that online learning in most cases in fact takes less time than that of the traditional face-to-face course (p. 603).

The technology aspect of distance learning is not as easily measurable as other concepts previously mentioned. Technology familiarity is linked to age along with gender throughout many studies (e.g. Ashby, 2003; Biner, Bink, Huffman, \& Dean, 1995; Dick \& Hanna, 2002; Kleen \& Shell, 2001; Sehoole \& Moja, 2003). One study showed that female students, who were the traditional age of 25 and under, had lower satisfaction in the course than their male classmates due to the technology used and their merstanding of how to use all the technology available to them (Kleen \& Shell, 2001). Another study showed the contradicting results that traditional aged females tended to be more satisfied with the technology options available to them and utilized more of those options than their male counterparts (Stoke, 2003). These two studies highlight that the technology aspect of distance learning is less concrete in terms of established measurement tools than some other demographic characteristics. What is lacking is a method for measuring computer literacy (Sehoole \& Moja, 2003; Zeller, 2005). Today’s students represent the first generations to grow up with this new technology. They have spent their entire lives using computers, video games, digital music players, video cams, cell phones, and other toys and tools of the digital age. Presnky (2001) notes that "today's students have not just changed incrementally from those of the past, nor simply changed their slang, clothes, body adornments, or styles, as has happened between generations previously. A big discontinuity has taken place" (p. 1). A method for measuring computer literacy needs to consider these differences between the generations. 
To date, there is no definitive answer to whether demographic characteristics such as age, gender or level computer literacy will be a predictor of satisfaction. The more studies that are done will help find if there is a link.

Quality of work

An important factor in determining the value of a course is the quality of work the course elicits from its students. As discussed earlier, concerns arise around the effectiveness and value of online courses. The biggest concern is that arises is that online courses diminish the academic integrity of the institutions (Maddux, 2004). Clark (2002) addresses this concern and discusses in detail nine myths of distance learning. One of the more important myths is "myth 2: E-learning is less effective than traditional methods of learning" (Clark, 2002, p. 599). Clark (2002) goes on to explain that participation is higher in the e-learning environment, leading to higher levels of cognitive engagement and therefore higher levels of retention. These higher levels of retention and participation would support the idea that students would get "more" out of the courses and therefore the quality of the coursework would be higher. There is more than just one way to view quality of work.

One way to address this concern would be to look at the work that is produced in these courses. The first approach would be from what angle the course approaches the topic: student centered or teacher centered. If a student has a more active role in their learning experience they should get more out of the class than if it is more teacher based (Kassop, 2003). In online courses, students are more in charge of their learning experience. They need to make sure they keep up with the technology along with any assignments posted via the web. In the traditional face-to-face classroom, the instructor 
is usually in charge of how the class will be taught and the students take a more passive role in the class (Kassop, 2003). With a class being student centered, whether it be online or face-to-face, there is more focus on writing (Clark, 2002; Kassop, 2003; Maddux, 2004). Kassop (2003) notes that

online courses are far more writing-intensive than traditional classes have ever been. In both F2F and online classes, major assignments are submitted in written form. But in an online course, general discussions, requests for elaboration or assistance, answers to directed questions, group projects, most assignments, and many tests and quizzes are in written form as well. The consensus among my online colleagues is that when instructors require that students submit carefully written and proofread assignments, the quality of many students' work improves over the duration of the course.

Kassop's claim would reinforce the use of an online component to produce a higher quality of work produced from the students.

The second approach to take would be to view what the student wants and needs as not necessarily the same thing. Sener and Humbert (2002) address this issue by stating that students do not always know what they want, and there are gaps between their wants and needs. Higher education institutions should try to make this gap as small as possible. In the study by Dick and Hanna (2002), the survey administered asked students to compare their online class to other similar classes they have taken. They found that the general outcomes, which included final grades, papers, how much the student felt they learned and comparisons to other courses they have taken, were the same no matter the method in which the course was taught (Dick \& Hanna, 2002). Students will view their grades throughout the course as an indicator to how good of a class it was - this is not an accurate measure for the course.

Besides the work in the course the instructors themselves need to be considered. If a course if offered by more than one professor, no matter the method, students may feel 
fifferently about the course based solely on the professor (Dick \& Hanna 2002; Serban, 2000). Dick and Hanna (2002) had four open ended questions added onto the students' final exam to see what could have made the course more affective. Some of the responses from students were based on the professor himself. They included "I felt challenged by the course and the professor" while another student in the class reported "I didn't feel challenged and feel I learned less compared to other classes I've taken" (Dick \& Hanna, p. 117). In those two statements alone, there are contradicting levels of satisfaction and quality of work from the student's point of view. Looking longitudinally would be the best way to approach the implications of professors. If a professor has high marks from students over a few years, then it would indicate that they are getting more out of the course than if a one time study was done. This is a concern of universities. This concept to analyze the professor will not be address in the current study but it is something that still needs to be addressed.

Expected Relationships between Student Satisfaction, Mode of Instruction and Quality of Work

The above literature review reveals a potential relationship between student satisfaction and mode of instruction, and between quality of work and mode of instruction. Aiming to explore this possibility, the following research questions and hypotheses are proposed for this study: 
Research Questions:

1. Do demographic factors, such as age, gender, and other individual differences, such as computer literacy, make a difference in the student's satisfaction with online vs. face-to-face instruction?

2. Does the mode of instruction affect the quality of the final project?

3. Does the mode of instruction affect the quality of writing?

Hypothesis:

1. Women will have different levels of satisfaction with online instruction, compared to men.

2. The classes that utilize some mode of face-to-face contact will produce a difference in quality of the final project than the class that is entirely online.

3. The classes that utilize some mode of online instruction will produce a difference in quality of the writing than the class that is entirely face-to-face.

In order to examine the relationship of the three concepts, a student satisfaction survey was used for the purpose of observation. In addition, relationships between the different modes of instruction and quality of work are investigated through comparing the semester long projects for each class to better understand the correlations of components of the variables. 


\section{Method}

Rarticipants

Participants in this study were a sample of undergraduate students enrolled in one of three sections of the required communication course, COM381, taught at the University of Rhode Island during the Spring 2005 semester. All three sections were taught by the same instructor and were fully enrolled. While some degree of selfselection might have taken place for the different section, one can assume that the baseline is comparable. A total of 90 students, 42 males and 48 females, were recruited from intact classes with their agreement to participate in this study. These participants were all students in the field of Communication Studies. The average age for participants was 21.5 years old. Among them, $54.5 \%$ were juniors, $33.3 \%$ were seniors and $97.8 \%$ reported to be Caucasian.

Procedures

Two methods were adopted in the present study. The first method was a survey. The second was an analysis of the students' work including a semester long Public Service Announcement and a written literature review.

Sampling Procedure for Survey. A survey method was adopted in the present study. Students in the COM381 classes were told that participation was completely voluntary. An alternative assignment (see Appendix B) was offered to students who chose not to participate. Ninety of the ninety-three students in the three sections volunteered for participation. The participant consent forms (see Appendix A) were read and signed either in person by the students or via WebCT for section 0200 , the section entirely online. After reading and signing the consent forms, participants were asked to 
finish the two parts of the survey (i.e., demographic information, Satisfaction Survey) (see Appendix C). The survey was conducted via WebCT for all three sections. For sections 3 (TR 2:00-3:15) and 4 (3:30-4:45) the survey was conducted during the regular class time. Section 0200 , WebCT took the survey at various times throughout the same week.

Sampling Procedure for Semester Long Projects and Literature Review. The students in COM381 had to create a Public Service Announcement for their group project. The consent form used to get their permission for participation in the survey was also used for analyzing the Public Service Announcements and the literature reviews (see Appendix A). The final video resulting from the group project was analyzed. Most of the group projects had two videos focusing on the same idea, where some key variable, such as beginnings or endings was modified, while the message was kept the same. Within each of the three sections was compared to the classes as a whole. The projects were analyzed by a convenience sample of 79 students at the University of Rhode Island. The students were enrolled in Communication Studies courses at the 100-, 200-, and 300level. These students used a video evaluation form (see Appendix D) to analyze the Public Service Announcements to form an objective opinion of the quality of the videos. The literature reviews were graded by the professor teaching the course; the grades were used post hoc to look at the quality of the work.

Measures

Two instruments were used in this study. The 35-item Satisfaction Survey (see Appendix C) developed by Stokes (2003) was used to test participants' satisfaction levels. The lower the score an individual gets on the satisfaction survey, the higher the 
level of satisfaction the person possesses in terms of mode of instruction. Based on the 35 items, Stokes (2003) extracted three predictors of satisfaction: temperament, preferred learning styles and demographic characteristics.

According to Stokes (2003), "demographic characteristics" included seven items: age, gender, university classification, grade point average, major, experience with the World Wide Web, and experience with Web-based courses. Examples of demographic item questions include "grade or education level" (university classification), "Have you ever taken a course that has a web-component (WebCT, online chat etc.)" (experience with Web-based courses), "In how your entire college career how many courses have you taken entirely by WebCT" (experience with Web-based courses), and "In your entire college career how many courses have you taken partially by WebCT while at URI" (experience with Web-based courses). All 35 items were randomly ordered within the inventory. A five-point Likert scale was used to measure participants' rement/disagreement with each item, with 1 indicating, "strongly agree" and 5 indicating "strongly disagree."

The questionnaire to determine the levels of student satisfaction was developed by Stokes (2003), "insights were gained from the review of literature, particularly from Biner, Dean, and Mellinger (1994) and Wernet, Olliges, and Delicath (2000), and input from a team of instructional technology experts comprising professors in the Instructional Technology program at The University of Alabama" (p. 10). Using the Cronbach's alpha method, the reliability coefficient for the scale's internal reliability with the research sample was 0.83 . 
For this study a 5-question qualitative evaluation (see Appendix D) was developed by Dr. Mundorf to measure the quality of work in the Public Service Pimouncements. The evaluation depicted the students' impressions of two videos. Then the students were asked to compare the two videos to each other. The videos had the same theme just differences in the beginning or ending of the video. The type of questions asked were open-ended in order to give the students freedom to be as specific as possible as to what they found good and bad in the video. Questions included: "How did this video impact you", "What is the strongest aspect of the video", "What is the weakest aspect of the video", and "What could the creators do to make this video more effective."

In this study, the scale and the evaluation were used to measure student satisfaction and quality of work through objective means. In the original study, there was no significant relationship between the temperaments of the participants and their preferred learning styles therefore the researcher decided not to include those two additional tests (Keirsey Temperament Sorter and Felder and Solomon's Index of Learning Styles) since they were not pertinent to the current study (Stokes, 2003).

\section{Data Analysis}

Data obtained through the satisfaction survey were recorded as a mixture of interval, ordinal and nominal data. Descriptive statistics were used to report age, gender, Pe/ethnicity, grade or education level, reason for taking the course, previously taken courses with a web-component, the number of courses take either entirely or partially by WebCT, and in those web-based courses, how many times (if any) met face-to-face with the professor. Responses to each statement as it related to satisfaction in the online 
ducational environment were reported using frequencies. Only one question, question 19 , needed to be recoded into the positive scale. The overall satisfaction score for each participant was obtained by adding the numeric values of the 17 satisfaction statements; the range of possible scores was 17 , indicating a high level of satisfaction, to 85 , indicating a low level of satisfaction. The mean score for the degree of satisfaction was 39.2. 


\section{Results}

The primary research questions and hypotheses for this study sought to find the relationships between student satisfaction and mode of instruction, and between mode of instruction and the quality of work. In order to address these research questions and hypotheses, descriptive statistics, ANOVA and Tukey tests were utilized to determine whether there was a statistically significant difference between the sections.

\section{Student Satisfaction Survey}

The descriptive statistics provided some interesting information. Eighty percent of the students surveyed had taken a course with a web-component and more than half of those students were female $(53 \%) ; 51 \%$ of the students had never taken a course completely by Distance Learning; $44 \%$ prefer to take more classes via Internet delivery; $42 \%$ prefer more of the course materials in their traditional face-to-face classes to be in a Web-based format; $75 \%$ would take another course that is web-based; and $100 \%$ of the WebCT class would recommend a web-based course to their peers.

WebCT was used in all three sections for exams and e-mails. The hybrid and online sections used WebCT for discussion among their group members. The online section $(M=127)$ utilized the discussion boards three times as often as the hybrid section $(M=23.14)$. The online section ranged in usage from 7 postings to one of the groups having 259 postings with the majority of the postings relating to the different Mssignments, while the hybrid section ranged in usage from 3 postings to 60 postings. This utilization of the discussion option through WebCT would help support the higher levels of satisfaction in the online section and the hybrid section. 
A one-way analysis of variance compared the mean satisfaction scores for subjects assigned to the three modes of instruction: face-to-face, hybrid, and entirely online. Note that the composite scale used was reverse coded: The lower the score an individual gets on the satisfaction survey, the higher level of satisfaction the person possesses in terms of mode of instruction. This was found to be statistically significant at the $p<.05$ level $[F(2,84)=4.074, p=.020]$. There was a significant difference in overall satisfaction between the online section and the face-to-face section; and the online section and hybrid sections. The reverse scored satisfaction index shows that the hybrid section was more satisfied $(M=37.06)$ than the completely face-to-face section $(M=43.03)$; and the WebCT section $(M=36.33)$ was more satisfied than the completely face-to-face section. Note that satisfaction levels were reversed coded, meaning that lower scores indicate greater satisfaction. The overall means for the hybrid section and the WebCT section did not significantly differ from each other. Even though there was no statistically significant difference between the hybrid and WebCT sections for the student satisfaction survey, the trend is consistent with the hypothesis, indicating greater satisfaction for the WebCT section.

A multiple regression test was used to view if any of the continuous demographic characteristics were predictors of satisfaction. These independent variables were not a significant predictor toward satisfaction. There was no significant difference in student satisfaction between males and females based on the section in which they were enrolled. While not significant, satisfaction was higher for men in the online section, while the hybrid section was associated with higher satisfaction levels for women. As seen in Table 1, males were the most satisfied in the WebCT section $(M=34.29)$; females were 
most satisfied in the hybrid section $(M=35.82)$. Apparently, mode of instruction is a key factor for student satisfaction.

Table 1

Means of Satisfaction Scale Based on Gender*

Gender

Males Females

Mode of

Instruction

\begin{tabular}{lll} 
Face-to-face & 45.55 & 41.83 \\
Hybrid & 37.71 & 35.82 \\
Online & 34.29 & 37.36 \\
Combined & 39.31 & 39.15 \\
\hline
\end{tabular}

Note. This table represents the mean scores of student satisfaction based by gender. (The lower the score, the higher the level of satisfaction.)

$* \mathrm{~N}=87$

Tests of between subject effects were conducted using the satisfaction scale as the dependent variable and then by section and "previously taken a course with a webcomponent"; section and gender; and section and education level. The results of the between subject tests showed no significant difference in satisfaction.

Another ANOVA was performed to look at particular questions between the sections along with within the sections themselves. The results of this test are as follows: there was significance between the section based on the degree of contact with the professor $[F(2,87)=3.538, p=.033]$; the section based on the preference to take more classes online $[\mathrm{F}(2,86)=5.012, \mathrm{p} .=009]$; and the section based on "studying at my 
choice of setting" and "time made course work load easier" $[F(2,86)=8.237, p=.001]$. curprisingly there was no significant effect at the $p<0.05$-level for section and success in completing the web-based activities $[\mathrm{F}(2,87)=1.918 ; \mathrm{p}=.153]$; section and preference for more course material in the traditional face-to-face classes to be in a web-based format $[\mathrm{F}(2,86)=.872 ; \mathrm{p}=.422]$; section and the statement "working in a web instructional environment enables me to take a more active role in the learning process" $[\mathrm{F}(2,87)=$ $.233 ; p=.793]$; and the section and "I learned more with a combination of face-to-face interaction and web-based than with just the traditional face-to-face classes" $[F(2,87)=$ $1.993 ; p=.142]$. Even though there were no statistically significant results, the means show a trend consistent with the hypotheses.

Quality of Work

Video Analysis

A one-way analysis of variance compared the mean quality of work scores of the videos for subjects assigned to the three modes of instruction: face-to-face, hybrid, and entirely WebCT. This was found to be statistically significant $[F(27,5)=4.781, p=.044]$. There was a significant, positive relationship between the overall effectives of the videos with the course in the face-to-face section and the online section; and the hybrid section and the online section. This indicates that the face-to-face section produced a higher quality of video $(M=7.3)$ than the WebCT section $(M=6.25)$; and the hybrid section produced a higher quality of video $(M=7.03)$ than the WebCT section. The means for the fee-to-face section and the hybrid section did not significantly differ from each other. The scale was from 0 to 10 , where 0 is the lowest, and 10 is the highest. Even though 
there was no statistically significant data between the face-to-face and WebCT sections for the videos, the trend is consistent with the hypothesis.

\section{Written Work}

A one-way analysis of variance compared the mean quality of work scores of the literature reviews for subjects assigned to the three mode of instruction: face-to-face, hybrid, and entirely WebCT. This was found to be statistically significant $[F(2,84)=$ 5.674, $\mathrm{p}=$.023]. There was a statistically significant difference in the quality of the writing in the literature reviews between the online section and the face-to-face section; and the online section and hybrid section. This indicates that the WebCT section produced a higher quality of writing $(M=9.28)$ than the face-to-face section ( $M=8.36$ ); and the WebCT section produced a higher quality of writing than the hybrid section $(M=8.21)$. The means for the face-to-face section and the hybrid section did not significantly differ from each other. The scale was from $0-10$, where 0 is the lowest and 10 is the highest. Even though there was no statistically significant data between the face-to-face and hybrid sections for the literature reviews, the trend is consistent with the bypothesis.

Discussion postings and student self-assessment papers were consulted to corroborate findings in quality of work. The student self assessment papers were for the students to detail all the work that their group had done up to that point in the semester, including who did what, weekly updates, and what the plan was for the rest of the project. The online section utilized the discussion boards three times as often as the hybrid section, however the online section video evaluations were the lowest. This could be due 
to the lack of equipment available to them to use for editing the project. On the other hand, the online section possessed the highest quality of written work in their literature reviews and their self-assessment papers were the most complete. The face-to-face section had the lowest quality of written work, but the highest quality for the video evaluations. Part of this may be attributed to the fact that this section had discussion in class rather than on WebCT. The face-to-face section student self-assessments were the lowest quality due to the lack of detailed information. Compared to the other sections, assignments by the face-to-face section lacked vital information such as work up to date (the weeks prior), what each person was responsible for, or the work still to be done. These results could be due to the fact that there is no transcript of what was said in the discussion. The students in the face-to-face class need to rely on their memory or notes taken during their discussions, while the online and hybrid sections have a record of what was said during their discussions. 


\section{Discussion and Conclusions}

This study investigated the relationship between student satisfaction and mode of mstruction, and between mode of instruction and quality of work. Overall, the results display moderate relationships between the concepts being measured. The mode of Instruction emerged as an important factor that influences a student's satisfaction with a course. Although no previous study has simultaneously examined these two concepts, student satisfaction and quality of work, by mode of instruction, these results are consistent with related studies on student satisfaction based on mode of instruction and studies between mode of instruction and quality of work. The results as well provide support for the argument that students do use the mode of instruction as a basis for satisfaction (Stokes, 2003).

\section{Student Satisfaction}

A positive relationship emerged between the level of online components and satisfaction with the course. The results suggest that as long as there was some webcomponent students were more satisfied. Furthermore it was expected that gender and age would influence this relationship. The results did not show a significant difference between female and male students, which is inconsistent with previous studies conducted (Allen \& Pilant, 2000; Belcheir \& Cucek, 2001; Stokes, 2003; Sullivan, 2001; Taplin \& Jegede, 2001). Due to the narrow range of the students' age, there was no influence on tatisfaction based on age. These results contradict previous studies that showed significant differences between traditional aged students and non-traditional aged students (Kleen \& Shell, 2001; Sullivan, 2001). 
Stokes (2003) suggested that, in general, student satisfaction was related to the mode of instruction and how it fit into the students' lives. Obviously, the data suggest that students attained higher satisfaction levels in a course that utilizes some form of a -component, and students had somewhat lower satisfaction levels in the traditional face-to-face course. Incorporating a web-component is the ideal method to influence students' satisfaction levels in a course because of the numerous advantages online learning possesses. It allows a student to work at his/her own pace, location, and schedule. The use of a web-component can also produce a more student centered learning environment which is more beneficial to students than a teacher based learning environment (Kassop, 2003).

Satisfaction was influenced by the time and setting in which the course was taken. For those students that utilized a web-component, there was significance in the fact that they could do their coursework at any time they wanted and at any location they wanted without being "locked" into the traditional form of a class. Although there were times when students needed to have things posted online by a certain day and time or have live chats, for the majority of the time, students could choose when they would do their work. Sullivan (2001) notes, "both men and women find the convenience and flexibility offered by online classes a major advantage over traditional classes" (p. 897). Therefore, the results strengthen Stokes' (2003) and Sullivan's (2001) findings that time saved was an indicator of satisfaction.

The results also shed an interesting light on the role of the amount of contact the professor has with the students. Previous studies reported that an instructor, who has more contact with his/her students and more interaction via e-mail, discussion, office 
hours etc., usually influences a student's perception of the class itself (e.g. Arbaugh, 2001; Swan, 2002; Witt, 2003). Thus, students are more willing to participate in discussion and ask questions than they would be if the instructor was not as available and had limited access or contact (Arbaugh, 2001).

The results are also consistent with pervious studies that have proposed to have more courses offered online. Sehoole and Moja (2003) suggested an increase in the number of courses offered via the Internet. The authors reported that a broader range of students can be reached and a more diverse student body can be obtained since students can take courses from anywhere in the world. Because diversity aids the learning process, institutions seek to have a diverse student body in their courses whether it is by age, race, gender, etc. Therefore, the more courses offered via the Internet, the more students can be reached and increase the diversity of the student body.

On the other hand, when students were asked if they wished more of the material in their traditional face-to-face courses were available online, there was no significant difference between the sections. Students prefer that their traditional face-to-face courses stay the way they are. These results coincide with the fact that students didn't feel they learned more with a combination of web-based and face-to-face learning. The results contradicted Kassop's (2003) findings that students feel they learned more in their hybrid courses than their traditional face-to-face counterparts.

One would assume that the more experience a student has with online learning the more satisfied they would be with the mode of instruction. The results of this study did not prove this to be true. Whether the course was completely online (Distance Learning), partially WebCT or entirely WebCT experience was not a significant indicator of 
atisfaction. Experience should aid in the predictability of the student satisfaction but was not the case in this study. Stokes (2003) found that "the number of previous courses that fincorporated web-based lessons taken by students was a predictor of satisfaction" ( $\mathrm{p}$. 14). In that study, the experience level would help support why some students were more satisfied than others, but in the current study it was not found to be a key factor. Quality of Work

A positive relationship between the videos created by the students and face-toface components of the course was expected, while online students apparently benefited from the increased level of writing typically associated with online teaching. The results suggest that as long as there was some level of face-to-face contact, the videos produced were a higher quality than if there was no face-to-face contact. This finding was to some extent influenced by the limited availability of editing facilities and support for the online students. Some limited editing resources were available to the face-to-face and hybrid students in the same building where the class was taught.

Clark (2002) suggested that the quality of work in courses with web components is just as good if not better than the traditional face-to-face courses. The data suggests that the videos were of higher quality in the courses that utilize some level of face-to-face contact. These finding contradict Kassop's (2003) claim that the use of an online component to produce a higher quality of work produced from the students. One reason could be that the students in the online course were an average of 23 years old while the average for the other two classes was 21 years old. Most studies use written work as the key outcome measure, which makes the current measure difficult to compare. 
In this study the structure of the sample might also be a plausible explanation of the result for the lack of significant relationship between student satisfaction and age, thnicity/race, or gender. If a sample included a more diverse population of students, there may have been a different outcome of their satisfaction levels. And since the majority of the students were Caucasian and in the traditional age range of students, there was not a diverse enough population to see if those factors would influence student atisfaction. As for the video analysis, if trained individuals evaluated the videos instead of the convenience sample the outcomes might have been different.

It was expected to see a positive relationship between the literature reviews written and the level of online components in the course. However, the results supported this speculation only in part. The WebCT course supported Kassop's (2003) and Clark's (2002) claims that online courses are more writing intense and the quality of the writing it higher compared to the face-to-face counterparts. However, the hybrid course did not support Kassop (2003) and Clark's (2002) claim. One reason could be that the students in the online course have less physical contact with the professor and thus utilized the forums, chats and discussion boards more often than the face-to-face students.

The overall conclusion for the quality of work is that courses utilizing a webcomponent, either partially or entirely, are more advantageous for writing assignments, while hands-on activities that require physical resources (e.g. editing, cameras) may benefit from a traditional face-to-face setting with the appropriate infrastructure.

\section{mplications}

This study contributes to our understanding of the interplay between student Atisfaction and mode of instruction; and between quality of work and mode of 
instruction. It also demonstrates the complexity of the nature of student satisfaction. Various factors could influence a student's level of satisfaction, with mode of instruction and quality of work as two factors. More studies are needed to examine the two concepts. The results of this study provide some potential implications to be put into practice. The findings may encourage professors to utilize a web-based component to aide in students' satisfaction and success in the course. Academic institutions may begin to use student satisfaction assessment to guide decision making, such as how many courses should be offered with a web-based component (either completely or partially) compared to how many are offered in the traditional face-to-face manner.

The study also lends support to the benefits of hybrid teaching modes, especially when hands-on components are involved (such as video editing or other equipment intensive work). It might be advantageous to create more 'blended' courses which take advantage of the individualized convenience of online teaching in combination with the immediacy and potential for hands-on learning in the face-to-face setting

The results of this study may also contribute to the design and implementation of an assessment for universities when still in the creating stage for courses. Hopefully, more instructors will receive the training as to what constitutes good use of the new phnologies. The results regarding the quality of work would suggest that more hybrid courses be offered to incorporate the advantages of both face-to-face and online Aucation, while writing intensive courses might benefit from an entirely online mode.

Despite the importance and the increased interest in online learning, facultytraining programs need to be conducted before the course starts (Kassop, 2003; Pelz, 2004). The present study may provide some knowledge in designing and evaluating a 
oulty-training program. Finally, the results could help institutions understand what contributes to student are satisfaction with the mode of instruction, and adjust their programs accordingly.

\section{Limitations and Conclusions}

The present study also has limitations, which may provide opportunities for future research. The first limitation relates to the small sample size. If a similar study was done on a larger scale, including numerous classes being offered in the three modes by the same professor, then a more accurate account could be found. Also, looking at classes from all different fields would allow the researchers to know what type of courses are better left in the traditional face-to-face method. Some types of courses, such as science labs, speech, and art cannot be taught online entirely, so those classes would need to be viewed if they can be taught partially online or completely face-to-face.

Another possible limitation of this study includes the particular sample employed to measure the quality of work. The convenience sample from university students used to analyze the Public Service Announcements may provide different results comparing with professors judging the same videos. The quality of work measured by "random" students rather than by qualified students and professors may also limit these results since the students do not have the same knowledge as what constitutes effective based on content rather than just visuals. On the other hand these students were the target audience for the PSAs targeting DUI and seatbelt use among college students.

To measure quality of work, the process could have been looked at as a process and not just the end result. For future studies, the projects and written assignments should be analyzed in a continuous manner. From the start of brainstorming, to how the 
students divide up work, to the drafts, and then the final project should all be taken into monsideration when measuring for quality of work. This would allow for the researcher to see which section of students improved the most over the period of time and not just look at a "snapshot" view. The end result of the project may not be an accurate account for which students did improve the most over the study.

Another major concern is that of selection bias. These three sections had maximum enrollment and students may have taken whatever class they could get. And since the course is required for all Communication Studies majors self-selection seems less of a factor than it would in an elective course. Still, students who are strong writers may tend to take the online courses since they know it will be more writing intense than the face-to-face sections. And some student may get the (wrong) impression that an online course is the "easy way out" and use that as a reason to enroll in those sections. One method to address this concern is to look at the student's GPA going into the course. Comparing the GPA's of all the students within the sections would provide a better comparison of the 'starting point' for each section. GPA was not asked for from the students in this study, but for future studies it would be beneficial to obtain this hormation. Another way to measure this would be to give the students a writing assignment at the beginning of the semester to gauge what their initial writing abilities are. Then by comparing the writing samples of each class to the other sections, would provide incite to which section has the stronger writers and address this concern of selection bias.

Overall, the results of this study provide some valuable information for our derstanding and application of mode of instruction, student satisfaction and quality of 
work. The present study attempts to shed some light on the relationship between these three important areas. More studies are encouraged to examine how and why the mode of instruction tends to influence one's satisfaction level in the course; it might also provide a better understanding of factors influencing the quality of work produced within these courses. 
The University of Rhode Island

\section{Appendices \\ Appendix A \\ Consent Form for Participants}

Department of Communication Studies

106 Independence Hall

Kingston, Rhode Island 02881

Title of Project: "An Examination of the Relationship Between Student Satisfaction and Teaching Style"

\section{CONSENT FORM FOR RESEARCH}

You have been asked to take part in a research project described below. The researcher will explain the project to you in detail. You should feel free to ask questions. If you have more questions later, Danielle Alfano, the person mainly responsible for this study, 874-7447, will discuss them with you. You must be at least 18 years old to be in this research project.

Description of the project:

You have been asked to take part in a study that is intended to investigate a person's satisfaction with faceto-face and web-faceted courses.

What will occur:

If you decide to take part in this study here is what will happen: First you will be asked to fill out a total of two sections of a questionnaire. In the first section, you will be asked to provide your demographic information such as gender, year of birth, grade and race. In the second section, you will be asked to quickly record your first impression by indicating the degree to which you agree or disagree with 16 statements.

Along with the survey, the work in the class as a whole will be observed. The main focus will be on your semester long Public Service Announcement. Your name will be removed from any posts, and you will be assigned a random number to ensure confidentiality. Portions of your WebCT posts or other submissions may be used to substantiate points made by the investigator. The researcher will read and analyze the posts to get a better understanding of the online learning experience.

Risks or discomfort:

There are no risks or discomforts associated with this study. Remember that you can refuse to answer any question. If you do not want to participate in the research, an alternative activity will be provided. Neither your participation nor your failure to participate will affect your student grade in this course in any way.

Benefits of this study:

Although there will be no direct benefit to you for taking part in this study, it may help you increase the knowledge regarding the variables of interest. You will have the experience of being a participant in a research study, and you instructor may discuss the research after the survey.

Mridentiality:

Your part in this study is confidential and your responses and comments will be held in confidence. None of the information will identify you by name. All records will secured and are available only to the researcher. Again, this study is anonymous. Your anonymity will be preserved. Once the information has been entered into the database it will no longer be attached to your name nor will there exist any other identifying information.

\section{Decision to quit at any time:}

The decision to take part in this study is entirely up to you. You do not have to participate. If you decide to take part in the study, you may quit at any time. Whatever you decide, in no way will your decision 
penalize y ou, a ffect y our g rade, or $s$ tatus a s a s tudent. If y ou w ish to quit, simply inform Ms. Danielle Alfano at (401) 874-7447 or dalf4438@postoffice.uri.edu of your decision.

Rights and Complaints:

If you are not satisfied with the way this study is performed, you may discuss your complaints with Ms. Danielle Alfano or with Dr. Norbert Mundorf at (401) 874-4725, anonymously, if you choose. In addition, you may contact the office of the Vice Provost for Graduate Studies, Research and Outreach, 70 Lower College Road, Suite 2, University of Rhode Island, Kingston, Rhode Island, telephone: (401) 874-4328.

You have read the Consent Form. Your questions have been answered. Your signature on this form means that you understand the information and you agree to participate in this study.

Signature of Participant

Typed/printed Name
Signature of Researcher

Danielle Alfano

Typed/printed name 
The University of Rhode Island

Department of Communication Studies

106 Independence Hall

Kingston, Rhode Island 02881

Student Satisfaction and Teaching Style

\section{TEAR OFF AND KEEP THIS FORM FOR YOURSELF}

Dear Participant:

You have been asked to take part in the research project described below. If you have any questions, please feel free to call Danielle Alfano at (401) 874-7447 or Dr. Norbert Mundorf at (401) 874-4725 (the people mainly responsible for this study).

The purpose of this study is to further knowledge about how individual's satisfaction of a course might influence one's behavior. You are asked to record your responses right in front of each statement. Confidentiality will be maintained as none of the information will identify you by name, again ensuring that your name is held confidential.

YOU MUST BE AT LEAST 18 YEARS OLD to be in this research project.

Wrou decide to take part in this study, your participation will involve filling out a total of one questionnaire pertaining to your satisfaction about this course, along with agreeing to allow Danielle Alfano to observe your classroom behaviors, mainly your Public Service Announcement.

possible risks or discomforts of the study are minimal, although some of you may feel some embarrassment answering questions about private attitudes. Remember that you can refuse to answer any question.

Mhough there are no direct benefits of the study, your answers will help increase the knowledge regarding your satisfaction with the style in which courses are taught.

Tour part in this study is anonymous. That means that your answers to all questions are private. No one else can know if you participated in this study and no one else can find out what your answers were. Scientific reports will be based on group data and will not identify you or any individual as being in this project. The research data will be kept for at least three years following the completion of the study.

lecision to participate in this research project is up to you. You do not have to participate and you can refuse to answer any question. Whatever you decide will in no way penalize you, affect your grade, or status as a student.

apation in this study is not expected to be harmful or injurious to you. However, if this study causes you any injury, you should write or call Danielle Alfano at (401)(874-7447) or Dr. Norbert Mundorf at $(401)(874-4725)$ both are located at the University of Rhode Island.

If you have any more questions or concerns about this study, you may contact

University of Rhode Island's Vice Provost for Graduate Studies, Research and Outreach, 70 Lower College Road, Suite 2, URI, Kingston, RI, (401) 874-4328.

You are at least 18 years old. You have read the consent form and your questions have been answered to your satisfaction. Your filling out the survey implies your consent to participate in this study.

Thank you,

Danielle Alfano 
Appendix B

Alternative Activity

This is a technology savvy society. How can utilizing the technologies help build more effective courses for college students?

What are some common connections for courses you have taken? What are the different ways of producing these connections?

What is student satisfaction for courses? Why it is important to take a course that incorporates a web component into the curriculum? And which do you prefer to use in your classes?

Thank you for your corporation and hope this activity will help you with Com381 topics. 
Appendix C

Satisfaction Survey

Question 1:

In which section of Dr. Mundorf's COM 381 are you enrolled?

a. Section 3, TR 2:00-3:15

b. Section 4, TR 3:30-4:45

c. Section 0200, WebCT

Question 2:

Age:

Question 3:

Gender

a. Male

b. Female

Question 4:

Race/Ethnicity

a. Hispanic or Latino

b. American Indian or Alaska Native

c. Asian

d. African American

e. Native Hawaiian or Other Pacific Islander

f. Caucasian

g. Biracial or Multiracial

h. Other

Question 5:

Grade or Education Level

a. Freshman

b. Sophomore

c. Junior

d. Senior

e. Nonmatriculated or other (not officially admitted to URI or other college/university; graduate student; etc.)

Question 6:

How many semesters have you been at URI (including Spring 05)?

Question 7:

Reason for taking course
a. Major requirement or elective within major field
b. Required course outside major field
c. General education elective
d. Free Elective 
Question 8:

Have you ever taken a course that has had a web-component (WebCT, online chat, etc)?

a. Yes

b. No

\section{Question 9:}

In how many of the online classes mentioned above did you meet face to face with your professor?

Question 10:

In how many of the online classes mentioned above was it a distance learning course where you only interacted via computer?

\section{Question 11:}

In how many of the online classes mentioned above did you meet face to face with your professor.

Question 12:

In your entire college career how many courses have you taken entirely by WebCT.

\section{Question 13:}

In your entire college career how many courses have you taken partially by WebCT while at URI.

\section{Question 14}

I am able to access a computer with an Internet connection to do my work for this class.
a. Strongly Agree
b. Agree
c. Neutral
d. Disagree
e. Strongly Disagree

Question 15:

I am satisfied with the degree of contact I have with my teacher when working through Web-based activities
a. Strongly Agree
b. Agree
c. Neutral
d. Disagree
e. Strongly Disagree 
Question 16:

I am pleased with the success I am having with completing the Web-based activities

a. Strongly Agree

b. Agree

c. Neutral

d. Disagree

e. Strongly Disagree

Question 17:

The resources I need for the Web lessons are readily available through the Internet.
a. Strongly Agree
b. Agree
c. Neutral
d. Disagree
e. Strongly Disagree

Question 18:

My technology knowledge level is sufficient for learning in a Web-based environment.
a. Strongly Agree
b. Agree
c. Neutral
d. Disagree
e. Strongly Disagree

Question 19:

I am feeling somewhat isolated from the University setting by taking a class that places emphasis on learning through Web-based activities.
a. Strongly Agree
b. Agree
c. Neutral
d. Disagree
e. Strongly Disagree

Question 20:

I would prefer to take more of my classes through Internet delivery.
a. Strongly Agree
b. Agree
c. Neutral
d. Disagree
e. Strongly Disagree 
Question 21:

Participating in a Web-based class has allowed me more flexibility in my daily activities.

a. Strongly Agree

b. Agree

c. Neutral

d. Disagree

e. Strongly Disagree

Question 22

I would prefer more of the course materials in my traditional face-to-face classes to be in a Web-based format.
a. Strongly Agree
b. Agree
c. Neutral
d. Disagree
e. Strongly Disagree

\section{Question 23:}

I believe that working in a Web instructional environment enables me to take a more active role in the learning process.
a. Strongly Agree
b. Agree
c. Neutral
d. Disagree
e. Strongly Disagree

\section{Question 24}

Communication with other students through WebCT is a positive experience.
a. Strongly Agree
b. Agree
c. Neutral
d. Disagree
e. Strongly Disagree

Question 25:

My Web-based class is providing me with skills that I can use in other courses.
a. Strongly Agree
b. Agree
c. Neutral
d. Disagree
e. Strongly Disagree 
Question 26:

I believe that the Web instructional environment is preparing me for technology use in my profession.
a. Strongly Agree
b. Agree
c. Neutral
d. Disagree
e. Strongly Disagree

Question 27:

I had sufficient interaction with the instructor.
a. Strongly Agree
b. Agree
c. Neutral
d. Disagree
e. Strongly Disagree

Question 28:

Studying at my choice of setting and time made course work load easier.
a. Strongly Agree
b. Agree
c. Neutral
d. Disagree
e. Strongly Disagree

Question 29:

I learned more with a combination of face-to-face interaction and Web-based than with just the traditional face-to-face classes.
a. Strongly Agree
b. Agree
c. Neutral
d. Disagree
e. Strongly Disagree

Question 30:

I would take another course that is Web-based.
a. Strongly Agree
b. Agree
c. Neutral
d. Disagree
e. Strongly Disagree 
Question 31:

Kingston classes only: Considering travel, registration and all other costs associated with this course; do you think this is less expensive than the traditional course held at the miversity?
a. Strongly Agree
b. Agree
c. Neutral
d. Disagree
e. Strongly Disagree

Question 32

WebCT class only (section 0200): I would recommend a Web-based course to my peers.
a. Strongly Agree
b. Agree
c. Neutral
d. Disagree
e. Strongly Disagree

Question 33:

I am satisfied with the group aspect in the class.
a. Strongly Agree
b. Agree
c. Neutral
d. Disagree
e. Strongly Disagree

Question 34

On average, how often did you meet online for your group project.

Question 35:

On average how often did you meet face-to-face for your group project. 
Appendix D

Video Evaluation

Please rate the video you just saw on a scale from 0 to 10 , where 0 is the lowest, 10 the highest:

How much did you like the video overall?

- How much did you like the visuals?

- How much did you like the audio/music?

How did this video impact you?

What is the strongest aspect of the video?

What is the weakest aspect of the video?

What could the creators do to make this video more effective?

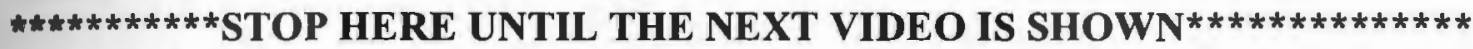
Please rate the video you just saw on a scale from 0 to 10 , where 0 is the lowest, 10 the highest:

How much did you like the video overall?

- How much did you like the visuals?

_ How much did you like the audio/music?

How did this video impact you?

What is the strongest aspect of the video?

What is the weakest aspect of the video?

What could the creators do to make this video more effective?

The last two videos you saw were somewhat similar. If you had a total of $\$ 100$ to award to both videos combined, how much would you give to each?

First video $\$$

Second video \$ 


\section{Bibliography}

Allen, K., Hartman, J., \& Truman, B. (1997). Learning from a distance education experience. Technology and Teacher Education Annual,1, 136-139.

Annison, J. (2002). Action research: Reviewing the implementation of a distancelearning degree program utilizing communication and information technologies. Innovations in Education \& Teaching International, 39(2), 95-107.

Arbaugh, J.B. (2001). How instructor immediacy behaviors affect student satisfaction and learning in web-based courses. Business Communication Quarterly, 64(4), 42-54. Armstrong, L. (2001). A new game in town: Competitive higher education. Information Communication \& Society, 4(4), 479-507.

Ashby, C. (2003). More data could improve education's ability to track technology at minority serving institutions. Washington, DC: Federal Document Clearing House.

Baer, W. (2000). Competition and collaboration in online distance learning. Information, Communication \& Society, 3(4), 457-473.

Barbian, J. (2002). Here's proof. Online Learning Magazine, 6(6), 27-31.

Barker, B., \& Baker, M. (1995). Strategies to ensure interaction in telecommunicated distance learning. Paper presented at the $11^{\text {th }}$ Annual Conference on Teaching and Learning, Madison, WI.

Belcheir, M., \& Cucek, M. (2001). Student perceptions of their distance education courses (Report No.BSU-RR-2001-04). Boise, ID: Boise State University. Office of Institutional Assessment. (ERIC Document Reproduction Service No. ED 480 923) 
Biner, P., Bink, M., Huffman, M., \& Dean, R. (1995). Personality characteristics differentiating and predicting the achievement of televised-course students and traditional-course students. American Journal of Distance Education, 9(2), 4660.

Biner, P., Welsh, K., Summer, M., \& Dean, R. (1997). The impact of remote-site group size on student satisfaction and relative performance in interactive telecourses. American Journal of Distance Education, 11(1), 23-33.

Breitborde, M., \& Swiniarski, L. (2002). Family education and community power: New structures for new visions in the educational village. Educational Studies, 28(3), 305-319.

Burnett, C. (2003). Learning to chat: Tutor participation in synchronous online chat. Teaching in Higher Education, 8(2), 247-262.

Clark, D. (2002). Psychological myths in e-learning. Medical Teacher, 24(6), 598-604. Clark, R.D. (1999). Going the distance. Black Enterprise, 29, 113-118.

Creanor, L. (2002). A tale of two courses: A comparative study of tutoring online. Open Learning, 17(1), 57-69.

De Lucena, C. (2002). The development and application of distance learning courses on the internet. Open Learning, 17(1), 23-39.

Dick, G., \& Hanna, M. (2002). Is on-line distance education a viable alternative for undergraduates? An experiment with the students in Georgia, the professor in Australia. Proceedings of the International Academy for Information Management Annual Conference: International Conference on Informatics Education Research, (17 ${ }^{\text {th }}$, Barcelona, Spain, December 13-15, 2002), 111-122. 
Egan, M., Sebastian, J., \& Welch, M. (1991, March). Effective television teaching:

Perceptions of those who count most...distance learners. Proceeding of the Rural Symposium, Nashville, TN.

ELRN Network. (2001). Distance learning white paper. Retrieved March 10, 2005 from http://www.elmnetwork.com/elrnwhitepaper.html

Encinas, F. (2002). Training for distance teaching through distance learning. Open Learning, 17(2), 139-144.

Haywood, T. (2000). Defining moments: The tensions between richness and reach. Information Communication \& Society, 3(4), 648-655.

Hiemstra, R., \& Sisco, B. (1990). Individualizing instruction. San Francisco: Jossey-Bass.

Retrieved December 13, 2004 from http://www-distance.syr.edu/andraggy.html Hyland, F. (2001). Providing effective support: Investigating feedback to distance language learners. Open Learning, 16(3), 233-248.

Johnson, L. (2000). Continuing dental education via an interactive video network:

Course development, implementation and evaluation. Journal of Educational Media, 25(2), 129-141.

Kassop, M. (2003). Ten ways online education matches, or surpasses, face-to-face learning. Retrieved March 12, 2005 from http://distance.wsu.edu/facultyresources/savedfromweb/10ways.htm Kaye, T. (1989). Computer supported collaborative learning in a multimedia distance education environment. Paper presented at the NATO Advanced Research Workshop, Maratea, Italy. 
Kelly, K., \& Schorger, J. (2002). Online learning: Personalities, preferences and perceptions. (Report No. TM034557). Missoula, MT: University of Montana. School of Education. (ERIC Document Reproduction Service No. ED 470 663)

Kleen, B., \& Wayne, S. (2001). SERVQUAL-Based measurement of student satisfaction with classroom instructional technologies: A 2001 update. Proceedings of the International Academy for Information Management Annual Conference; International Conference on Information Education \& Research, New Orleans, LA.

Kubala, T. (1998). Addressing student needs: Teaching on the internet. T.H.E. Journal, 25(8), 71 .

Kubala, T. (2000). Teaching community college faculty members on the internet. Community College Journal of Research \& Practice, 24(5), 331-340.

Kulik. (1994). Meta-analytic studies on findings in computer-based instruction. In E.L. Baker \& H.F. O'Neil (Eds.), Technology Assessment in Education and Training (pp. 155-172). Hillsdale, NJ: Prentice Hall.

Kulik, C., \& Kulik, J. (1991). Effectiveness of computer-based instruction; An updated analysis. Computers in Human Behavior, 6, 75-94.

Kurt, M., \& Overstreet, C. (2003). The essential elements of interactive multimedia distance learning systems. Journal of Distance Education Technologies, 1 17-36. Rauzon, A. (1992). Integrating computer-based instruction with computer conferencing: An evaluation of a model for designing on-line education. American Journal of Distance Education, 6, 32-46. 
Leach, L. (2002). Appropriate pedagogy and technology in a cross-cultural distance education context. Teaching in Higher Education, 7(3), 309-322.

Levin, J. (2005). The business culture of the community college: Students as consumers; students as commodities. New Directions for Higher Education, 129, 11-26.

Maddux, C. (2004). Developing online courses: Ten myths. Rural Special Education Quarterly, 23(2), 27-32.

Martin, E., \& Riney, L. (1993). Student achievement and attitude in a satellite-delivered high school science course. The American Journal of Distance Education, 7(1), 54-61.

Martinson, D. (2000). Student evaluations of teaching and their short term validity. Journalism \& Mass Communication Educator, Winter 2000, 77-82.

McCoy, D., \& Sorensen, C. (2003). Policy perspectives on selected virtual universities in the United States. The Quarterly Review of Distance Education, 4, 89-107.

Michau, F., Gentil, S., \& Barrault, M. (2001). Expected benefits of web-based learning for engineering education: Examples in control engineering. European Journal of Engineering Education, 26(2), 151-169.

Pelz, B. (2004). (My) three principles of effective online pedagogy. $J A L N, 8(3), 33-46$.

Percy, C. (2003). Critical absence versus critical engagement. Problematics of the crit in design learning and teaching. Art, Design \& Communication in Higher Education, 2(3), 143-154. 
Prensky, M. (2001a, September/October). Digital natives, digital immigrants. On the Horizon, 9(5), 1-6. Retrieved April 30, 2004, from http://www.marcprensky.com/writing/Prensky\%20\%20Digital\%20Natives,\%20Digital\%20Immigrants\%20-\%20Part1.pdf Reisman, D. (1981). On higher education: The academic enterprise in an era of rising student consumerism. San Francisco: Jossey Bass.

Roach, R. (2004). Online education critical to higher education, survey says. Black Issues in Higher Education, 21(21), 36-39.

Saba, F. (2001). Distance education: An introduction. Retrieved January 4, 2005 from http://www.distance-educator.com/intro.htm Sehoole, C., \& Moja, T. (2003). Pedagogical issues and gender in cyberspace education: Distance education in South Africa. African and Asian Studies, 2(4), 475-496. Sener, J., \& Humbert J. (2002). Student satisfaction with online learning: An expanding universe. Retrieved December 12, 2004 from http://sln.suny.edu/sln/public/original.nsf/dd93a8da0b7ccce0852567b00054e2b6/ 755285ffb5847a4385256c3c006246ea/\$FILE/Student\%20Satisfaction\%20\%20John\%20Sener\%20and\%20Joeann\%20Humbert.doc

Serban, A. (2000). Evaluation of fall 1999 online course. (Report No. JC-010-422). Santa Barbara, CA: Santa Barbara City College. (ERIC Document Reproduction Service No. ED 453 868)

Shea, P., Fredericksen, E., Pickett, A., Pelz, W., \& Swan, K. (2001). Measures of earning effectiveness in the SUNY learning network. Proceedings of the Workshop 2000 on Asynchronous Learning Networks, New York, New York. 
Snare, C. (1997). Implications of considering students as consumers. College Teaching, 45(4), 122-123.

Souder, W. (1993). The effectiveness of traditional vs. satellite delivery in three management of technology master's degree programs. The American Journal of Distance Education, 7(1), 37-53.

Stokes, S. (2003). Temperament, learning styles, and demographic predictors of college student satisfaction in a digital learning environment. Internet and Higher Education, 4, 31-44.

Sullivan, P. (2001). Gender differences and the online classroom: Male and female college students evaluate their experiences. Community College Journal of Research \& Practice, 25(10), 805-819.

Swan, K. (2002). Building learning communities in online courses: The importance of interaction. Education, Communication \& Information, 2(1), 23-49.

Taplin, M., \& Jegede, O. (2001). Gender differences in factors influencing achievement of distance education students. Open Learning, 16(2), 133-154.

Thorpe, M. (2002). Rethinking learner support: The challenge of collaborative online learning. Open Learning, 17(2), 105-120.

Whittington, N. (1987). Is instructional television educationally effective? A research review. The American Journal of Distance Education 1(1), 47-57.

Willet, J.B., Yamashita \& Anderson. (1983). A meta-analysis of instructional systems. Journal of Research in Science Teaching, 20, 405-417. 
Witt, P. (2003). Enhancing classroom courses with intemet technology: Are course web sites worth the trouble? Community College Journal of Research \& Practice, 27(5), 429-439.

Zeller, T. (2005, January 17). Measuring literacy in a world gone digital. The New York Times, p. C-1.

Zheng, L., \& Smaldino, S. (2003). Key instructional design elements for distance education. The Quarterly Review of Distance Education, 4, 153-166. 